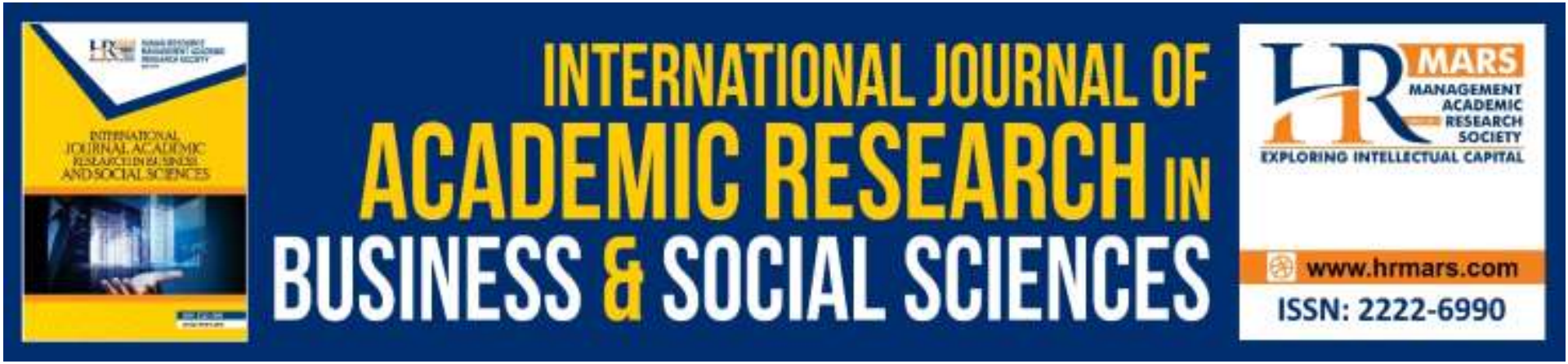

\title{
Analyzing the Relationship of Ethical Work Climate, Job Satisfaction, Organizational Commitment and Job Performance in Tabanan University, Bali
}

Anak Agung Gede Putra, Ida Bagus Agung Dharmanegara, Putu Ngurah Suyatna Yas

To Link this Article: http://dx.doi.org/10.6007/IJARBSS/v9-i9/6405

DOI: $10.6007 /$ IJARBSS/v9-i9/6405

Received: 16 July 2019, Revised: 02 August 2019, Accepted: 30 August 2019

Published Online: 22 September 2019

In-Text Citation: (Putra, Dharmanegara, \& Yas, 2019)

To Cite this Article: Putra, A. A. G., Dharmanegara, I. B. A., \& Yas, P. N. S. (2019). Analyzing the Relationship of Ethical Work Climate, Job Satisfaction, Organizational Commitment and Job Performance in Tabanan University, Bali. International Journal of Academic Research in Business and Social Sciences, 9(9), 1100-1115.

Copyright: @ 2019 The Author(s)

Published by Human Resource Management Academic Research Society (www.hrmars.com)

This article is published under the Creative Commons Attribution (CC BY 4.0) license. Anyone may reproduce, distribute, translate and create derivative works of this article (for both commercial and non-commercial purposes), subject to full attribution to the original publication and authors. The full terms of this license may be seen at: http://creativecommons.org/licences/by/4.0/legalcode

Vol. 9, No. 9, 2019, Pg. 1100 - 1115

http://hrmars.com/index.php/pages/detail/IJARBSS

JOURNAL HOMEPAGE

Full Terms \& Conditions of access and use can be found at http://hrmars.com/index.php/pages/detail/publication-ethics 


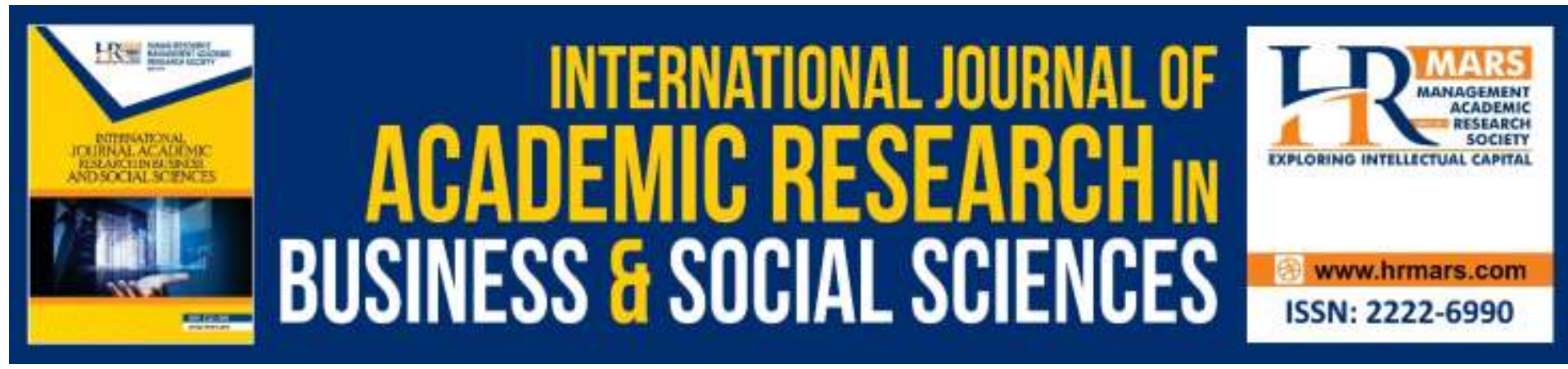

\title{
Analyzing the Relationship of Ethical Work Climate, Job Satisfaction, Organizational Commitment and Job Performance in Tabanan University, Bali
}

\author{
Anak Agung Gede Putra, Ida Bagus Agung Dharmanegara, \\ Putu Ngurah Suyatna Yas \\ Magister of Management, Faculty of Economic, Warmadewa University, Denpasar, Bali,
} Indonesia

\begin{abstract}
The primary aim of this research is to identify determinants of job performance and attitudinal mechanism process, which are considered as consequence factors for the ethical work climate in organization. The purpose of this quantitative study was to better understand the relationship of perceived ethical work climate on the organizational commitment, job satisfaction, and job performance among lecturers in institutions of higher education. Among 61 lecturers were taken as respondents who have to participate in this study. All of hypotheses proposed in this study are accepted, with linear relationship among variables as general findings. Both of individual attitudes (satisfaction and commitment) founded to be exactly different with previous empirical findings when they related with ethical work climate and job performance. Ethical work climate found as better predictor for job satisfaction, while the effect of organizational commitment on job performance is greater than job satisfaction. Future research study is recommended to explore how perceived ethical climates may differ in another form of organizations, in order to clarify the concepts of ethical climate with both attitudinal and behavioral outcomes.
\end{abstract}

Keywords: Ethical Work Climate, Job Satisfaction, Organizational Commitment, Job Performance.

\section{Introduction}

As one of high educational institutions, universities are considered as the most complex organizations in Indonesia. The competition they always face with other educational institutions could be seen as vicious as any corporate boardroom, with having no individual shareholders, yet society in their circumstances as the largest stakeholders. Tabanan University (Untab) is considered as reputable private university in Tabanan Regency. Out of 8 Regencies and 1 City in Bali Province, only 3 Regencies have Universities. As a center of excellence in the development of science and technology and human resources, Tabanan 
University is determined to realize competent, entrepreneurial and cultured human beings (Siwirabuda in Balinese).Particularly in Indonesia, lecturer's performance would be examined from the activities of the higher education (tridharma activities consist of education, research, and service to community or society) and how much it could be produced in a certain of period.

Lecturers are the forefront employees of any higher educational institution, and they have a direct impact on the successful implementation of the vision, mission, and goals of the university. It is imperative to understand potential factors influencing their job performance with organizational commitment and job satisfaction because decreased levels of commitment and satisfaction have been linked to lower productivity. Initial observation in Tabanan University indicates that lecturers' performance is still categorized as low. The lack of implementation of higher education Tridharma such as the results of research and community service, because under the higher educational regulation lecturers are required to have at least one study, one article and one community service in each semester. Text book and other educational content material is a learning media that must be sought to be continuously updated. Within the research in various organizations, many possible causes or correlates of individual performance have been identified, including leadership characteristics, social support, client characteristics, and salary and benefits.

Lecturer performance is inseparable from job satisfaction from what is received and felt by the lecturer itself as a return on services to the profession, job satisfaction is a pleasant emotional attitude and loves his job this attitude is reflected by work morale, discipline and performance. Generally lecturers are responsible the profession he is doing is very afraid to be undisciplined, to not perform well, and not to be present at work, not to communicate well when with students, fellow teachers, staff and leaders, not to have maximum commitment to the organization and not have competence. Ajzen, (2011) affirms the pattern of relationship of satisfaction - performance through the theory of planned behavior. Although there is no denying the fact that in the relationship between job satisfaction and individual performance, there are inconsistencies in the results that show findings that job satisfaction is found to be not important for improving performance (Dinc \& Plakalovic, 2016; Hidayat \& Ferdiansyah, 2013; Subakti, 2013).

Commitment is considered as important factor that could influences the lecturers 'performance of implementing the Tridharma of Higher Education. Consistency in commitment is considered as an important aspect, in which this not only carried out by officials in management but members of the organization must carry out and doing all programs and rules in order to reach organizational goal. Individual commitment to organizations has been an important area of research in the study of organizational behavior for decades (Riketta, 2002; Suliman, 2002; Susanty \& Miradipta, 2013) . Several previous studies have examined the relationship between commitment and individual characteristics, such as perceived competence, age, gender, time, marital status, education, and salary (Mathieu \& Zajac, 1990). Today some researchers such as Dinc \& Plakalovic (2016) reveal findings that organizational commitment is not important to individual performance. This inconsistency result existed in a pattern of relationships between commitment and performance. The presence of an ethical climate in organizations is important as a result of globalization in today's organizations and increasing competition. Therefore administrators in a public organization such as universities need to know the impact of the ethical climate on employee behavior. The search has shown that employees work in a more productive way in 
terms of a clear and positive ethical climate than in terms of uncertain ethical standards. Thus, an ethical climate is assumed to influence the formation of employee attitudes and behavior (DeConinck, 2010; Martin \& Cullen, 2006). In addition, the presence of an ethical climate in organizations has a more important role for sustainable organizational growth. This condition results in positive self-employment and the organization that employees depend emotionally on the organization they work for (Ismail, 2015). Thus, managers or supervisors always wanted to have employees with higher organizational commitment. Previous literature suggested a positive relationship between organizational ethical climate and organizational commitment (Cullen, Parboteeah, \& Victor, 2003; Dharmanegara, Pradesa, Tanjung, \& Harijanto, 2016; Chwepker, 2001) with specific effect on affective commitment (Pradesa, 2018; Pradesa, Dawud, \& Affandi, 2019). Because emotionally commitment is based on volunteerism rather than obligation, it could bring more impact on greater productivity and a positive ethical climate than other aspects of commitment.

The application of ethics in organizations is very important and needs to be implemented in various life activities to create good moral values (Fauzan, 2015), this is mainly as a basis for individual attitudes and behaviors in an organization. Ethical climate has a significant influence on employee attitudes and behavior of an organization. Empirical findings, which have been carried out in many Western countries, find a relationship between ethical climate and various types of work outcomes, such as job satisfaction (Huang, You, \& Tsai, 2012; Pradesa, 2018; Schwepker, 2001) and organizational commitment (Huang et al., 2012; Ismail, 2015).Some empirical studies have linked the importance of an ethical work climate in encouraging individual ethical attitudes and behavior. Situational and dispositional interaction factors can play an important role in the behavior of individuals in the organization. In this case it shows the importance of examining and investigating the effects of an ethical climate in influencing individual attitudes and behaviors in the organization. But even with an ethical climate in universities, this does not necessarily improve the performance of lecturers. Interesting things will arise when considering both job satisfaction and organizational commitment as things that are seen to strengthen the impact of the ethical work climate. It also would be interesting to further explore whether job satisfaction and organizational commitment could strengthen the impact of an ethical work climate in influencing indirectly on improving the performance of lecturers.

Previous studies reveal the relationship between job satisfaction and the ethical climate types are vary. Therefore, the purpose of this study is to further understand the relationship between the perceived ethical work climate, job satisfaction, organizational commitment, and the job performance of lecturers. There is a gap between ethical work climate and individual behavior especially among people who are dedicated to the professional and ethical standards of higher education. Are they performs better in doing the job because of committed to the organization in which they work or satisfied in their job?

Based on the phenomenon described above indirectly will have an impact on improving the performance of educators in this case is a lecturer at Tabanan University. It is important to be able to know and analyze the factors that influence the performance improvement of the lecturers. Based on this, the researcher feels the need to review important things in being interested in choosing the theme of lecturer performance at Tabanan University which is influenced by the ethical work climate indirectly through job satisfaction and organizational commitment to lecturers who work at Tabanan University. 


\section{Research Purpose and Problems}

To date, all of the previous research on ethical work climate has focused upon what will benefit organizational members most and what will cause them the least amount of harm. In order to address the shortcomings of past research, this study focused on lecturers in the private university and how their perception of ethical climate influences their attitude and behavior.

The primary purpose of this research is to analyze the effect of ethical work climate on job performance through job satisfaction and commitment. This study was motivated by a gap in the literature on understanding how organizational ethical work climate affect job performance brought about by the attitudinal mechanism of lecturer in private university. Ethical work climate and attitudinal mechanism each have a different focus and explanation of the successful job performance. The influences of ethical work climate on job performance through satisfaction and commitment were examined. Since ethical work climate is seen as one of core factor to build important individual attitudinal mechanism in organization, a practical framework proposed in this study based on the results of evaluation of our proposed model with empirical data.

This study helps to reduce the reliance on assumption and to provide evidence for the existence and nature of these relationships. Our literature review integrated concepts from the fields of organizational behavior, and based on our review of relevant literature from these fields, we propose that job performance created through the organizational attitudinal mechanism process forms the basis from practical application ethical climate. Causal and influencing relationships among the proposed research constructs are reviewed in detail in the literature review section.

However, a reading of the ethical climate and organizational behavior literature suggests that no one from each perspective can sufficiently explain this complex phenomenon. This study was undertaken to meet this challenge by examining the perception of the ethical work climate with attitudinal and behavioral outcomes concurrently in the context of an ongoing effort to build greater performance among lecturers in the private university in Indonesia.

\section{Literature Review}

Much research has been conducted on both ethical work climate and employee's job satisfaction and organizational commitment. In this section, the major components of the research framework and the dynamic relationships among them are reviewed.

\section{Relationship of Ethical Climate on Satisfaction and Commitment}

In studios that have been previously agreed upon are considered as linkages ushered in an ethical work climate towards attitudes such as job satisfaction and organizational commitment (Cullen et al., 2003; DeConinck, 2010; Schwepker Jr., 2001). Job satisfaction is recognized as a form of one's attitude to his work, while organizational commitment is known as a form of one's attitude towards the organization (Natalie J. Allen \& Meyer, 1991; Shore \& Martin, 1989). Findings revealed that higher education support professionals were more satisfied with their job, their salaries, and benefits. In general, satisfaction and commitment are important things that must be managed and maximized by organizations.

Commitment is an important issue for higher education organizations to examine as a lack of organizational support and commitment was a leading cause of employee turnover (Mathieu \& Zajac., 1990). Understanding the impact of effect ethical work climate upon 
organizational commitment will foster organizations to adjust in how they would communicate employees' ethical values and behaviors and increase the perception about ethical climate. Ethical climate may be a significant factor in shaping attitudes and behaviors of employees (Cullen et al., 2003; DeConinck, 2010; Dharmanegara et al., 2016).

When Cullen et al., (2003) discusses the ethical work climate as a multidimensional construct and each dimension can affect the attitudes and work of employees. Job satisfaction in the context of the Organizational climate was previously agreed upon in previous empirical research (e.g. Deshpande, 1996; Elci \& Alpkan, 2009; Martin \& Cullen, 2006; Wang \& Hsieh, 2012). Some of the previous researchers have discussed the relationship between ethical work and job satisfaction in various types of work and industry. In general there is an important link between the ethical work climate towards the form and type of job satisfaction, such as satisfaction with salary, promotion, coworkers, superiors, and the work itself (Deshpande, 1996). These empirical findings indicate that job satisfaction is seen as an important empirical result of ethical work. In general, the more positive the work environment prepared by individuals in the organization will encourage the more satisfied someone at the time of working. Although in some respects certain dimensions of the ethical work environment encourage employees to be more satisfied (Ambrose, Arnaud, \& Schminke, 2008; Babin, Boles, \& Robin, 2000; Deshpande, 1996). In addition to job satisfaction, organizational commitment is seen as another variable that is routinely issued in the initial literature. Regarding job satisfaction, many previous studies concerning the relationship between work dimensions and ethics (Ambrose et al., 2008; Babin et al., 2000; Cullen et al., 2003). Although some of these studios highlight the construct validity of the ethical work climate, the statistically significant relationship between ethical climate and commitment is found in full.

According to Webber, (2007) it is the part of self-interest among individual that poses the largest threat to the decrease of the ethical work climate. It is significant to underline that healthy ethical work climates would give employees a formal means for confronting threats to ethical performance, with no matter what ethical climate type and organization may fall under. In addition, the Ethical Climate Questionnaire has been previously determined to analyze the effect of ethical work climate regarding employee outcomes such as organizational commitment, job satisfaction, and dysfunctional behavior (Webber, 2007).In particular, ethical work climate often related with specific dimension of commitment, such as affective commitment (I.B.A. Dharmanegara et al., 2016; Pradesa, 2018; Pradesa et al., 2019). These empirical findings will leads to the fact that it is better to work ethically perceived by the lecturer will encourage tube more satisfied with the lecturer for the work he does.

\section{Job Satisfaction and Performance}

The Job Characteristics Theory (Hackman \& Oldham, 1980) emphasized that employees will be more satisfied with job if it includes a variety of work dimension and fosters feelings of responsibility. The relationship between job satisfaction and performance seems more clearly measured, but also more controversial than that of motivation from work and job performance, as illustrated by research by Judge \& Klinger, (2007) and Hulin \& Judge, (2003). Job satisfaction is how individuals feel content related to their work (Hulin \& Judge, 2003; Judge \& Klinger, 2007). Job satisfaction, individual attitudes and job performance are all interrelated. In simple terms, job satisfaction is a person's attitude towards their duties (both positive and negative). Commonly argued that satisfied employees can perform all tasks more 
efficiently and effectively, while employees who feel dissatisfied feel pressured then cannot do their jobs properly. The problems that occur generally are employees who have high job satisfaction but do not become employees with high productivity. Many opinions suggest that higher job satisfaction is mainly generated by work performance. Better work performance results in higher rewards. If the award is felt fair and adequate, then employee job satisfaction will increase because they receive awards in a proportion that is in accordance with their work performance. Therefore, job satisfaction is important for employees and organizations especially for creating positive work results for the organization.

Since long time ago job satisfaction is an important and main predictor of employee performance (laffaldano \& Muchinsky, 1985; Shore \& Martin, 1989). Other research (e.g. Schermuly et al., 2011) presumes that job satisfaction could be treated as independent variable that is also as a predictor of other attitudes and behaviors in the organization. Many previous research vary that may create confusion when assessing the effect of job satisfaction in the organization. To build a better understanding of job satisfaction, researchers suggested that staff and administrators are motivated by organizational commitment, feeling appreciated or having a purpose (Fuller et al., 2006).

Although some findings reveal the absence of significance of satisfaction with employee performance (Dinc \& Plakalovic, 2016; Hidayat \& Ferdiansyah, 2013; Subakti, 2013); in general the generalization of the results of the importance of job satisfaction in predicting employee performance has been widely recognized and examined in general in various studies (Awan \& Islam, 2015; Dharmanegara, Sitiari, \& Adelina, 2016) . In general, if it is drawn to the context of higher education, it could be assumed that lecturers who are more satisfied with their work will tend to be better able to produce better performance.

\section{Organizational Commitment and Performance}

Job performance is closely related to organizational goals, as a result of one's work behavior. Forms of performance behavior could be traced to specific factors such as ability, effort and task difficulties (Sonnentag \& Frese, 2002). Performance as a result of the pattern of actions taken to achieve goals in accordance with achievement standards, qualitative and quantitative, which have been determined by individuals in person and by the organization where the individual works (Sonnentag \& Frese, 2002; Tett, Fox, \& Palmer, 2003; Welbourne, Johnson, \& Erez, 1998). Performance is often identified with the results of one's feelings related to commitment to the organization. Organizational commitment is a structural phenomenon of trade between individuals and organizations that could increase over time, but cannot produce transferable investment results. Thus, in theoretical studies and practical use, scientists often have highly valued organizational commitment in managing human resources.

An individual who is committed to the organization will choose to remain, accept, and believe in the goals of the organization and provide the best effort to achieve these goals (Allen \& Meyer, 1990). Committed employees will always strive to be able to give and do their best because they have positive feelings towards the organization, where this is demonstrated through work effort which then improves the performance they display. In addition to job satisfaction, commitment is seen as important in encouraging employee performance (Suliman, 2002). The findings of previous studies support this premise by revealing that organizational commitment has an important effect on employee performance (Shore \& Martin, 1989; Subakti, 2013; Susanty \& Miradipta, 2013). Relationship between 
commitment and performance is interpreted positively and significantly (Dharmanegara et al., 2016; Suliman, 2002) meaning that the higher organizational commitment will improve employee performance. In the context of higher education institutions, it can be assumed that the higher the organizational commitment felt by the lecturers, the higher the performance showed by the lecturer.

Mediating Role of Satisfaction and Commitment in the Effect of Ethical Climate on Performance

Previous empirical results underline the importance of individual attitude mechanisms such as job satisfaction and organizational commitment in mediating an ethical work climate with behavioral outcomes such as tuning intention (DeConinck, 2010).

The empirical findings show that both job satisfaction and organizational commitment can act as intervening variables in a causal model of research. Previous author such as Zehir, Erdogan, \& Basar, (2011) examined ethical work climate as an antecedent variable for both job satisfaction and organizational commitment. The ethical work climate directly influenced job satisfaction and organizational commitment. At the same time, ethical work climate indirectly affect organizational commitment through job satisfaction. Another previous scholar, Nafei, (2015) examined ethical work climate that is exerted as an independent variable that influence on both job satisfaction and organizational commitment. Finding of this research also revealed positive correlations of varying strength for sub-dimension of the ethical work climate.

In general, congruence between the ethical work climate towards attitudinal and behavioral outcomes has been widely recognized before (e.g. Dharmanegara et al., 2016; Huang et al., 2012; Ismail, 2015) but if this is related to results a person's behavior on his job (e.g. performance) and his organization (e.g. turnover intention) has the potential to provide a different understanding. It is assumed that a positive increase in the ethical work climate cannot provide important meaning for improving the performance of lecturers directly. The impact of individual perceptions on the ethical work climate is seen as more effective when there is intervention from how much a person becomes satisfied with his job and or more committed to his organization.

\section{Framework and Hypotheses}

This study was guided by the concerns based on theory of planned behavior (TPB), and this study assumed that employees of the same organization had different perceptions of the ethical climate and different levels of satisfaction and commitment,

The conceptual framework that guided this study hypothesized that perceptions of ethical work climate would affect the level of satisfaction and commitment. Thus, this would lead to increasing job performance among lecturers in private university. Based on a literature review, a research framework was developed (see Figure 1). The framework of the research model is built based on the description in theoretical and empirical studies and describes the overall hypothesis of this research shown in the figure as follows: 


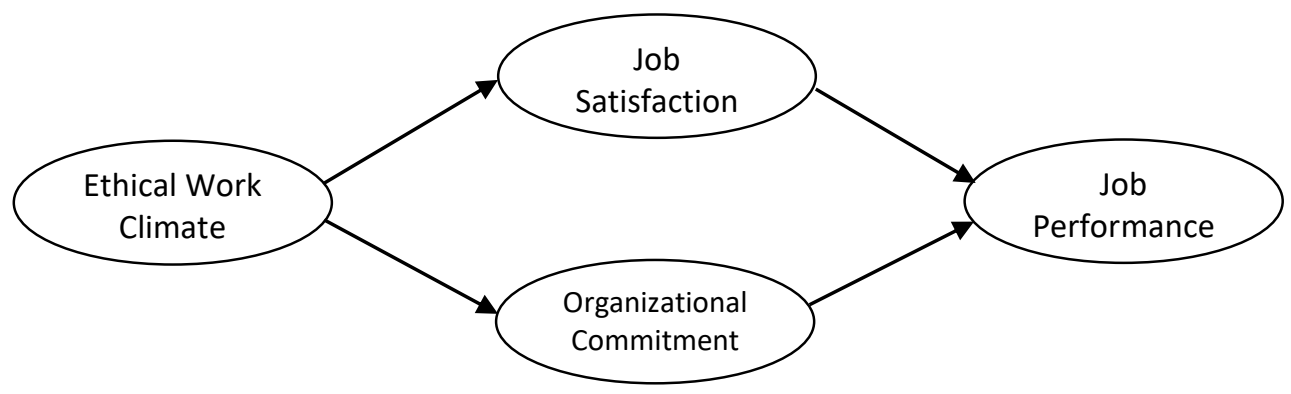

Figure 1.Conceptual Framework

The following is a brief explanation of the model. To examine structural and influential factors among determinants of lecturers 'job performance in private university, the following six hypotheses were derived from the research framework and associated theoretical base of the literature review.

H1 Ethical work climate could have increase job satisfaction among lecturers

$\mathrm{H} 2$ Ethical work climate could have increase organizational commitment among lecturers

H3 Job satisfaction could have increase job performance among lecturers

$\mathrm{H} 4$ Organizational commitment could have increase job performance among lecturers

H5 Ethical work climate has a positive significant effect on lecturer performance through job satisfaction

H6 Ethical work climate has a positive significant effect on lecturer performance through organizational commitment

\section{Methodology}

In this section, several method-related issues are presented, including the data collection procedure, research instruments and data analysis strategies.

\section{Data Collection and Sample Framework}

This study was conducted in a private university in Bali that owns 3 faculties and has 61 lecturers (34 national certified and 27 not yet certified). An invitation to complete the questionnaire was distributed electronically to all lecturers that identified in university. Total of 61 lecturers were participate in the study, in which perfect response rate among population identified.

Based on the research objectives that have been formulated, this study was conducted with a Positive Research approach, namely quantitative research on the measurement of constructs that form a model and analyze the relationship between one construct and another construct. Based on the purpose of the study, the design of this study included the type of explanatory research. Explanatory research in this case aims to find an explanation or explanation of why an event or symptom occurs. This study seeks answers by analyzing the relationship between variables of ethical work climate, job satisfaction, organizational commitment and performance for lecturers who work at Tabanan University.

Based on the perspective of time of implementation, this study was categorized as a crosssectional study. The cross-sectional study is a study conducted at one time, and research is not to compare the results at different times. In this study, what was determined as the location of the study was located at Tabanan University. As one of the private sector colleges 
from Tabanan University, it has become a concern for its stakeholders. Therefore, choosing Tabanan University as an object of research is inseparable from the purpose of exploring the performance that the lecturers working at the institution have displayed.

The estimated time for conducting this study ranged between approximately one month, particularly in March 2019, taking into account the process of retrieving data through questionnaires and structured interviews for lecturers who worked at Tabanan University, Bali and who were the samples or respondents in this study.

\section{Instruments}

The primary purpose of this research was to examine structural relations of four research constructs to measure direct and indirect impacts to practices of ethical work climate and job performance. Questions foreach construct were sourced from previously validated instruments. All quantitative questionnaire items were measured with a five-point Likert-type scale ( 1 strongly disagree to 5 strongly agree).

First, to measure the level of ethical work climate, the dimensions of EWC questionnaires (EWCQ) was used (Victor \& Cullen, 1988). The survey covered a variety of items including measures of various dimension of ethical climate which consist of caring, law, instrumental, independence, rules and codes (EC1-EC5). Second, to evaluate the level of job satisfaction, a work-related job satisfaction scale with three items was used (based on Colquitt, Lepine, \& Wesson, 2009; Hulin \& Judge, 2003), specifically focusing on lecturers' job satisfaction. These scales measured the levels of satisfaction for pay, promotion, peer, supervisor, and job itself (JS1-JS5). Based on the experiences of the researchers, the items were combined and reworded to better fit a university context while keeping the original concepts and intended meaning of the scales. One of the sample items included is: I have a good salary comparing with other organization.

Third, six items were used to measure the level of organizational commitment (Allen \& Meyer, 1990). These measures were developed by Allen \& Meyer (1990), and modified and shortened by Zhou and George in 2001 based on an analysis of the scale's internal consistency. Fourth, to measure job performance, 5 sub dimensions were used to evaluate five factors of job performance among lecturers in private university.

It is assumed that the measures selected will accurately measure the constructs intended. All measures have been named for human service populations, making them relevant to this study. They all have been validated through empirical studies and have good validity and reliability. This will help to ensure that they accurately measure what they are intended to for this study.

\section{Discussion of the Findings}

Table 1 shows basic descriptive summary statistics of the responses and the Cronbach's alpha estimates of the research construct items. Means, standard deviations, and factor loadings for all indicators are presented in Table 1.In the measurement model, confirmatory factor analysis was conducted for each of the latent variables to examine the validity of the measures were tested to check, whether all the confirmed items of constructs are accepted. In confirmatory factor analysis all the constructs tested individually with their items. Multiple stages tested are used on measurement model. At the first stage, all latent constructs were correlated to test the measurement model fitness of all constructs. Initial results signaled a weak model fit and item loadings of the constructs. The results of the initial factor loadings of 
items EC1, EC2, JS5, JP1, JP4, and JP5 were removed from the further analysis due to low value of factor loading, rest of the items were retained.

Two of ethical work climate dimension (caring, rules and procedures) are found insignificant based on its loading factor, and yet one of job satisfaction indicator (satisfaction for work itself) is found to be insignificant. Three of job performance indicators (work quantity, working presence, and cooperating with others) are found to be insignificant in job performance's construct.

Discriminant validity was examined by calculating the shared variances between pairs of variables. The results demonstrated that they were lower than the average variance extracted by each latent construct. All measures proved to be reliable where the composite reliability scores were greater than 0.60 . Summary statistics and correlations between variables are given in Table I below.

Table 1. Average of Variance Extracted, Mean of Variables, Standard Deviation and Intercorrelations

\begin{tabular}{|c|c|c|c|c|c|c|c|}
\hline Variables & AVE & VAVE & $\begin{array}{c}\text { Mean } \\
\text { (SD) }\end{array}$ & 1 & 2 & 3 & 4 \\
\hline \multirow[t]{2}{*}{ 1.Ethical Work Climate } & & & 3.85 & $(.85)$ & & & \\
\hline & 0,57 & 0,75 & $(.746)$ & & & & \\
\hline \multirow[t]{2}{*}{ 2.Job Satisfaction } & & & 3.91 & $0,69 * *$ & (.89) & & \\
\hline & 0,52 & 0,72 & $(.816)$ & & & & \\
\hline \multirow{2}{*}{$\begin{array}{c}\text { 3.Organizational } \\
\text { Commitment }\end{array}$} & & & 3.86 & $0,77 * *$ & & $(.87)$ & \\
\hline & 0,64 & 0,80 & $(.731)$ & & 0,13 & & \\
\hline \multirow[t]{2}{*}{ 4.Job Performance } & & & 3.96 & $0,69 * *$ & & $0,70 * *$ & $(.85)$ \\
\hline & 0,54 & 0,73 & $(.856)$ & & $0,68 \cdots$ & & \\
\hline
\end{tabular}

Notes: ${ }^{* *} p, 0.01 ;{ }^{*} p, 0.05 ;$ Cronbach's alphas for each scale are italicized and shown in the diagonal.

Instrument reliability in this study was measured using Cronbach's alpha, with internal consistency estimates for the construct measures in proposed model were adequate. Cronbach's alpha was .85 for ethical work climate, .89 for job satisfaction, .87 for organizational commitment and .85 for job performance. The means range from 3.85 to 3.96 and the standard deviations range from .731 to.856. The mean score for job performance was 3.96, indicating the highest average score among variables in this study. Furthermore, the mean score for ethical work climate, job satisfaction, organizational commitment, and job performance were 3.85, 3.91, 3.86 and 3.96 .

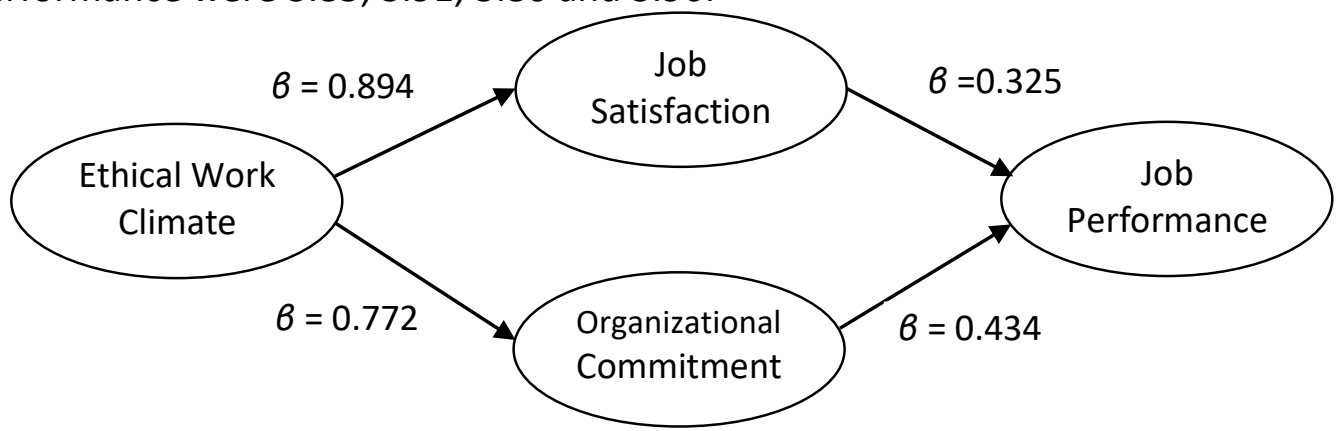

Figure 2.Path Coefficients between Variables 
Where job performance was associated more with organizational commitment, job satisfaction commitment was solely influenced by ethical work climate. Ethical work climate in Tabanan University was correlated with how much they are satisfied with their job. These findings contradict previous research. Many of the researchers (Hulin \& Judge, 2003; laffaldano \& Muchinsky, 1985; Judge \& Klinger, 2007; Tett et al., 2003) found that job satisfaction played a greater role in building individual performance. However, this study found that employees who feel that they are commitment treated fairly were likely to stay with an organization. They also found that individuals who feel more emotionally attached are tend to be more productive.

As figure 2 demonstrates, the pathway from ethical work climate to job satisfaction ( $p>0.05$ and $\beta=0.894)$ and the pathway from ethical work climate to organizational commitment ( $p>0.05$ and $\beta=0.772)$ is positive and significant. The pathway from job satisfaction to job performance is likewise positive and significant ( $p<0.01$ and $\beta=0.325$ ). Also findings reveal that pathway from organizational commitment to job performance is positive and significant $(p<0.01$ and $\beta=0.434)$.

A significant and positive relationship exists between the two dependent variables, total organizational commitment and total job satisfaction. The data indicate that as a faculty member reports higher levels of organizational commitment, they also report higher levels of job satisfaction. Administrators may be able to use this information to help facilitate positive organizational outcomes for their university.

In summary, all of the six hypotheses were accepted for this research study. Overall, it appears that the perception a faculty member holds with regard to their organization's ethical work climate has a strong relationship to both their self-reported levels of organizational commitment and job performance. Data also suggest that respondents tended to report higher level of ethical work climate would increase job satisfaction higher than to organizational commitment. University administrators could possibly use these findings to increase positive organizational outcomes at their institutions of higher education.

\section{Conclusion and Recommendations}

Lecturers in Tabanan University tend to perform well in their task when they are more committed to the organization, in which this is caused by positive perception of ethical work climate. Being more satisfied to their job will make lecturers perform well. But performance of the lecturer is seen as the most important result of the form of a teacher's attachment to the organization compared to the results of the extent to which the lecturer feels satisfied with the factors inherent in his work. Therefore, it is important to note that the ethical work climate in this study presented are only based on the perception of the lecturers as participant and may not reflect the prevalent ethical climate of the institution.

Theoretically this research shows that some concepts related to the mechanism of individual attitudes in organizations could give different results. It is proven that conceptually job satisfaction which is predicted to have the most important effect on individual performance is found to be inconsistent with the results of the study. Research findings have revealed that organizational commitment has more influence on job performance than job satisfaction. On the other hand, the measurement of constructs in research provides an illustration that the nature of the variables observed in the study of behavior is more dynamic and not rigid. Different research contexts and places allow this to happen, where previously 
standardized concepts such as ethical work climate, job satisfaction, and performance must be reduced in their indicators of variables. It was found that only organizational commitment in terms of construct size still fulfilled and in accordance with the original concept (consisting of three indicators namely affective, normative, and continuous organizational commitment).

Establishment of an organization's ethical climate, however, is not limited to administrators. Peer-to-peer relationships also provide critical insight into workplace norms and the current organizational climate. The need to create a positive and good ethical work climate in the organization that is considered more ethical by all elements. The importance of this ethical work climate is a must be clearer understood by all of lecturers in who would be contribute to increase organizational performance.

This study does not distinguish samples based on personal characteristics, including assessing the relationship with personal perceptions that are felt for things other than those listed in the model. Because this research focuses more on examining the causality relationship between exogenous and endogenous variables whose measurement instruments are developed from previous theoretical and empirical studies. Similar research in the future by modifying the research model and adding other concepts studied in order to provide a deeper explanation of the patterns of relationships between attitudes (towards work, towards the organization) and individual behavior in other particular organization.

\section{Acknowledgment}

The authors would like to express their gratitude to all lecturers who took part in this study.

\section{Corresponding Author}

Ida Bagus Agung Dharmanegara

Head of Department of Management, corresponding author.

Email: gusdhewun@gmail.com

Faculty of Economic, Warmadewa University of Denpasar, Bali, Indonesia

\section{References}

Ajzen, I. (2011). Job Satisfaction, Effort, and Performance : A Reasoned Action Perspective. Contemporary Economics, 5(4), 32-43.

Allen, N. J., \& Meyer, J. P. (1990). The measurement and antecedents of affective, continuance and normative commitment to the organization. Journal of Occupational Psychology, 63(1), 1-18.

Allen, N. J., \& Meyer, J. P. (1991). A Three Component Conceptualization of Organizational Commitment. Human Resource Management Review, 1(1), 61-89.

Ambrose, M., Arnaud, A., \& Schminke, M. (2008). Individual Moral Development and Ethical Climate:The Influence of Person-Organization Fit on Job Attitudes. Journal of Business Ethics, 77, $323-333$.

Awan, A. G., \& Islam, M. (2015). Relationship Between Satisfaction, Attitude and Performance: A Case Study of MCB Bank Ltd. Journal of Marketing and Consumer Research, 7, $11-18$.

Babin, B. J., Boles, J. S., \& Robin, D. P. (2000). Representing the Perceived Ethical Work Climate Among Marketing Employees. Journal of the Academy of Marketing Science, 28, 345 358.

Colquitt, J. A., Lepine, J. A., \& Wesson, M. J. (2009). Organizational Behavior: Improving 
Performance and Commitment in The Workplace. New York: McGraw - Hill / Irwin.

Cullen, J. B., Parboteeah, K. P., \& Victor, B. (2003). The Effects of Ethical Climates on Organizational Commitment: A Two-Study Analysis. Journal of Business Ethics, 46, 127141.

DeConinck, J. B. (2010). The Influence of Ethical Climate on Marketing Employees' Job Attitudes and Behaviors. Journal of Business Research, 63, 384-391. https://doi.org/10.1016/j.jbusres.2008.11.009

Deshpande, S. P. (1996). The Impact of Ethical Climate Types on Facets of Job Satisfaction: An Empirical Investigation. Journal of Business Ethics, 15(6), 655-660.

Dharmanegara, I. B. A., Pradesa, H. A., Tanjung, H., \& Harijanto, D. (2016). Becoming Emotionally Attached to Team: The Role of Ethical Climate Dimension in Nursing Profession. In Proceeding 15th Anniversary PDIM FEB Universitas Brawijaya International Conference (pp. $105-120$ ).

Dharmanegara, I. B. A., Sitiari, N. W., \& Adelina, M. E. (2016). The impact of organizational commitment, motivation and job satisfaction on civil servant job performance in State Plantation Denpasar. Journal of Business and Management, 18(2), 41-50. https://doi.org/10.9790/487X-18224150

Dinc, M. S., \& Plakalovic, V. (2016). Impact of Caring Climate, Job Satisfaction, and Affective Commitment on Employees' Performance in the Banking Sector of Bosnia and Herzegovina. Eurasian Journal of Business and Economics, 9(18), 1-16. https://doi.org/10.17015/ejbe.2016.018.01

Elci, M., \& Alpkan, L. (2009). The Impact of Perceived Organizational Ethical Climate on Work Satisfaction. Journal of Business Ethics, 84(3), 297-311.

Fauzan. (2015). Pengaruh Religiusitas dan Ethical Climate Terhadap Ethical Behavior. Modernisasi, 11(3), 187-202.

Fuller, J., Hester, K., Barnett, T., Frey, L., \& Relyea, C. (2006). Perceived organizational support and perceived external prestige: Predicting organizational attachment for university faculty, staff, and administrators. The Journal of Social Psychology, 146(3), 327-347.

Hidayat, C., \& Ferdiansyah. (2013). Pengaruh Motivasi dan Kepuasan Kerja Terhadap Kinerja. Binus Business Review, 2(1), 379-386.

Huang, C. C., You, C. S., \& Tsai, M. T. (2012). A multidimensional analysis of ethical climate, job satisfaction, organizational commitment, and organizational citizenship behaviors. Nursing Ethics, 19(4), 513-529.

Hulin, C. L., \& Judge, T. A. (2003). Job attitudes: A theoretical and empirical review. In W. C. Borman, D. R. Ilgen, \& R. J. Klimoski (Eds.), Handbook of psychology (pp. 255-276). New Jersey: Wiley.

laffaldano, M. T., \& Muchinsky, P. M. (1985). Job Satisfaction And Job Performance : A Meta Analysis. Psychological Bulletin, 97(2), 251- 273.

Ismail, S. (2015). Effects of Ethical Climate on Organizational Commitment, Professional Commitment, and Job Satisfaction of Auditor in Malaysia. Gadjah Mada International Journal of Business, 17(2), 139-155.

Judge, T. A., \& Klinger, R. (2007). Job satisfaction: Subjective well-being at work. In M. Eid \& R. Larsen (Eds.), The science of subjective well-being (pp. 393-413). New York: Guilford Publications.

Martin, K. D., \& Cullen, J. B. (2006). Continuities and Extensions of Ethical Climate Theory: A Meta-Analytic Review. Journal of Business Ethics, 69(2), 175-194. 
Mathieu, J. E., \& Zajac., D. M. (1990). A Review and Meta Analysis of The Antecedents, Correlates, and Consequences of Organizational Commitment. Psychological Bulletin, 108(2), $171-194$.

Nafei, W. (2015). The Influence of Ethical Climate on Job Attitudes. International Business Research, 8(2), 83-99.

Pradesa, H. A. (2018). Peran Komitmen Afektif Dalam Memperkuat Dampak Dari Dimensi Iklim Kerja Etis Terhadap Perasaaan Berkewajiban Pegawai Negeri Sipil di Kantor Pemerintahan Provinsi Jawa Barat. Jurnal IImiah Bisnis Dan Ekonomi Asia, 12(2), 16-29.

Pradesa, H. A., Dawud, J., \& Affandi, M. N. (2019). Mediating Role of Affective Commitment in The Effect of Ethical Work Climate on Felt Obligation Among Public Officers. JEMA: Jurnal Ilmiah Bidang Akuntansi Dan Manajemen, 16(2), 133-146.

Riketta, M. (2002). Attitudinal Organizational Commitment and Job Performance: A metaanalysis. Journal of Organizational Behavior, 23(3), 257-266.

Schermuly, C., Schermuly, R., \& Meyer, B. (2011). Effects of Vice Principals' Psychological Empowerment on Job Satisfaction and Burnout. Journal of Education Management, 25(3), 252-264.

Schwepker, J., C. H. (2001). Ethical Climate's Relationship to Job Satisfaction, Organizational Commitment, and Turnover Intention in the Salesforce. Journal of Business Research, 54, 39- 52.

Sen, A. (2012). Dharma Concepts in Emotional Intelligence. Vision: The Journal of Business Perspective, 16(2), 93-99. https://doi.org/10.1177/097226291201600202

Shore, L. M., \& Martin, H. J. (1989). Job Satisfaction and Organizational Commitment in Relation to Work Performance and Turnover Intentions. Human Relations, 42(7), $625-$ 638.

Sonnentag, S., \& Frese, M. (2002). Performance Concepts and Perfromance Theory. In S. Sonnentag (Ed.), Psychological Management of Individual Performance (pp. 3-25). New Jersey: John Wiley and Sons Inc.

Subakti, A. G. (2013). Pengaruh Motivasi, Kepuasan, dan Sikap Kerja Terhadap Kinerja Karyawan di Cafe X Bogor. Binus Business Review, 4(2), 596-606.

Suliman, A. M. T. (2002). Is it really mediating construct? The Mediating Role of Organizational Commitment in Work Climate - Performance Relationship. Journal of Management Development, 21(3), 170-183.

Susanty, A., \& Miradipta, R. (2013). Employee's Job Performance: The Effect of Attitude toward Works, Organizational Commitment, and Job Satisfaction. Jurnal Teknik Industri, 15(1), 13-24. https://doi.org/10.9744/jti.15.1.13-24

Tett, R. P., Fox, K. E., \& Palmer, P. C. (2003). Task \& Contextual Performance. In 18th Annual Conference of the Society for I and O Psychology (pp. 1-40). Orlando.

Victor, B., \& Cullen, J. B. (1988). The organizational bases of ethical work climates. Administrative Science Quarterly, 33, 101-125.

Wang, Y. D., \& Hsieh, H. H. (2012). Toward a better understanding of the link between ethical climate and job satisfaction: A Multilevel analysis. Journal of Business Ethics, 105, 535545.

Webber, S. (2007). Ethical climate typology and questionnaire: A discussion of instrument modifications. The Journal of Academic Librarianship, 33, 567-580. https://doi.org/10.1016/j.acalib.2007.05.003 
Welbourne, T. M., Johnson, D. E., \& Erez, A. (1998). Ther Role-Based Performance Scale : Validity Analysis of Theory-Based Measure. Academy of Managemet Journal, 41(5), 540555.

Zehir, C., Erdogan, E., \& Basar, D. (2011). The Relationship among Charismatic Leadership, Ethical Climate, Job Satisfaction, and Organizational Commitment in Companies. Journal of Global Strategic Management, 10, 49-58. 